\title{
Short communication: Effect of genetic type on antioxidant activity of Caciocavallo cheese during ripening
}

\author{
Annamaria Perna, ${ }^{1}$ Immacolata Intaglietta, Amalia Simonetti, and Emilio Gambacorta \\ School of Agricultural, Forestry, Food and Environmental Sciences, University of Basilicata, Potenza, Viale dell'Ateneo Lucano 10-85100, Italy
}

\begin{abstract}
The aim of this work was to investigate the antioxidant activity of Caciocavallo cheese made from the milk of 2 breeds, Italian Brown and Italian Holstein, and ripened for $1,30,60,90$, and $150 \mathrm{~d}$. The antioxidant activity of cheese was measured using the 2,2'-azinobis-3-ethylbenzothiazoline-6-sulfonic acid (ABTS), ferric-reducing antioxidant power (FRAP), and thiol assays. Statistical analysis showed a significant effect of the studied factors. Italian Brown cheese had higher antioxidant activity than Italian Holstein cheese, and antioxidant activity increased during ripening of both cheeses types. Moreover, antioxidant activity varied during ripening depending on the rate of formation of soluble peptides. To date, few studies have evaluated the effect of genetic type on antioxidant capacity of the pasta filata cheeses; thus, this study forms the basis of new knowledge that could lead to the production of a pasta filata cheese with specific nutraceutical characteristics.
\end{abstract}

Key words: Caciocavallo cheese, genetic type, ripening, antioxidant activity

\section{Short Communication}

Cheese was and remains a staple in Western diets, representing a large part of total milk product consumption in many countries, including France, Greece, and Italy. Although cheese has had an adverse nutritional image due to the association of saturated fatty acids, cholesterol, and salt content with cardiovascular diseases, it is a rich source of proteins, vitamins, and minerals (especially calcium in a highly bioavailable form), and of short-chain fatty acids and certain trans fatty acids that can be considered part of a healthy diet.

During cheese ripening, casein is hydrolyzed into a large variety of peptides by an enzymatic system that consists of proteases of different origins (predominantly

Received November 12, 2014

Accepted March 14, 2015.

${ }^{1}$ Corresponding author: anna.perna@unibas.it pepsin, trypsin, and chymotrypsin), fermentation of milk with proteolytic starter cultures, or proteolysis by enzymes derived from microorganisms or plants (Korhonen and Pihlanto, 2006). Many authors have reported that the proteolytic system plays an important role in the release of various bioactive peptides from the precursor protein where they are encrypted; these peptides influence different biological functions, such as antioxidant activity (Addeo et al., 1992; Smacchi and Gobbetti, 1998; Saito et al., 2000; Donkor et al., 2007). The domains within the milk proteins responsible for antioxidant activity have been identified (Kudoh et al., 2001; Rival et al., 2001; Hernandez-Ledesma et al., 2005a,b).

The biopeptides generated during ripening can be beneficial for oxidative defense by preventing the formation of free radicals or scavenging free radicals and active oxygen species that induce oxidative damage to biomolecules and cause aging, cancer, heart diseases, strokes, and arteriosclerosis (Fridovich, 1999). Previous research has reported that casein represents the primary substrate for proteolysis by bacterial starter and is a reserve for a wide variety of bioactive peptides (Meisel, 1998). Many studies have reported the relationship between antioxidant activity and concentration of low-molecular-weight peptides (Kudoh et al., 2001; Virtanen et al., 2007; Gómez-Ruiz et al., 2008). Moreover, many authors have shown that the antioxidant activity of CN could be related to its high tendency to chelate metals (Rival et al., 2001) and ability to donate electrons and atoms (Colbert and Decker, 1991).

Caciocavallo cheese is a typical product of southern Italy. It is a pasta filata cheese of medium or long proteolytic-lipolytic ripening, produced exclusively from raw cow milk, and coagulated with lamb rennet paste. Pasta filata cheese is made by stretching the acidified curd in hot water to about $80^{\circ} \mathrm{C}$. This stretching leads to alignment of the paracasein matrix and coalescence of fat and moisture into elongated pools parallel to the protein fibers (Battistotti and Corradini, 1993); stretching also influences proteolysis (De Angelis and Gobbetti, 2011). The physicochemical, nutritional, and organoleptic characteristics of Caciocavallo cheese are closely related to milk quality, which can change ac- 
cording to genetic and physiological factors of the cow (De Marchi et al., 2008). Many reports described the influence of addition of starter and nonstarter cultures on the antioxidant activity of cheese (Gupta et al., 2009), whereas the effect of livestock factors, such as genetic type, have not yet been well established.

The objective of this study was to assess the effect of genetic type (GT; Italian Holstein or Italian Brown) on antioxidant activity of water-soluble extracts of Caciocavallo cheese at different stages of ripening $(1,30$, 60,90 , and $150 \mathrm{~d}$ ) using the 2,2'-azino-bis-3-ethylbenzothiazoline-6-sulfonic acid (ABTS), ferric-reducing antioxidant power (FRAP), and thiol assays.

Thirty Caciocavallo cheeses produced with milk of 2 breeds (IB and IH) reared indoors on the same farm in the province of Potenza (southern Italy) were used in this experiment. All cows received the same feed ration, which was calculated according to their daily requirements for maintenance and production. Feeding was based on the use of silage and dried alfalfa hay as the main forage sources and concentrates based on ground corn and soybean meal. The cows were in good clinical condition, and the results obtained from analysis of individual milk showed a mean SCC of 4.89 $\log _{10}$ cells/mL, a value below the legislative limit established by the European Union (2004). For each group (15 animals), all milk from the morning milking was collected to make a composite sample, for a total of 2 composite samples (2 GT). On the same dairy farm, 15 Caciocavallo cheeses (average weight of $2.2 \mathrm{~kg}$ each) were produced from each composite sample at the same time and under the same conditions, which were then ripened for different periods: 1, 30, 60, 90, and $150 \mathrm{~d}$.

After milking, the milk was filtered to remove foreign substances, heated to 37 to $38^{\circ} \mathrm{C}$, coagulated by using lamb rennet paste (177 international milk clotting units $/ \mathrm{mL} ; 40.0 \mathrm{mg} / \mathrm{kg})$, and inoculated $(3 \%, \mathrm{vol} / \mathrm{vol})$ with a natural whey starter $(\mathrm{pH} 3.8)$. The natural whey starter was obtained by incubating, at $42^{\circ} \mathrm{C}$ for about $24 \mathrm{~h}$, fresh whey derived from the Caciocavallo cheese manufacture of the previous day. Lactic acid bacteria load of the natural whey starter, measured on de Man, Rogosa, and Sharpe and M17 media at $37^{\circ} \mathrm{C}$, ranged from $10^{6}$ to $10^{7} \mathrm{cfu} / \mathrm{mL}$. The coagulum was first cut coarsely, heated under whey at $45^{\circ} \mathrm{C}$ for $2 \mathrm{~h}$, milled into pieces of about $1.5 \mathrm{~cm}$, and held at room temperature until the $\mathrm{pH}$ reached approximately 5.3. When the acidified curd was ready, it was manually stretched in hot water $\left(70-80^{\circ} \mathrm{C}\right)$. Caciocavallo cheeses were dipped in brine $(27-30 \% \mathrm{NaCl})$ for $24 \mathrm{~h}$ and then ripened at 10 to $12^{\circ} \mathrm{C}$ and 75 to $80 \%$ relative humidity.

Sixty milliliters of distilled water was added to $20 \mathrm{~g}$ of grated Caciocavallo cheese and the mixture was placed in an ultrasonic water bath (Elma Transsonic 460/H,
Singen, Germany) for $10 \mathrm{~min}$. The homogenates were centrifuged (CR 4.12, fixed-angle rotor; Jouan, Saint Herblain, France) at $5,000 \times g$ at $4^{\circ} \mathrm{C}$ for $20 \mathrm{~min}$. The upper fat layer was discarded and the water extract was retained. The water-soluble extracts (WSE) were filtered on paper filter and, to remove any further impurities, were then filtered through a membrane filter $(0.45 \mu \mathrm{m})$ and used to measure the antioxidant activity.

A modification of the original method of Re et al. (1999) was applied to assess the scavenging capacity of WSE in a reaction with the ABTS radical cation $\left(\right.$ ABTS $\left.^{\bullet+}\right)$, generated by oxidation of ABTS diammonium salt stock solution with potassium persulfate $\left(\mathrm{K}_{2} \mathrm{~S}_{2} \mathrm{O}_{8}\right)$. Stock solutions of ABTS $(7 \mathrm{mM})$ and potassium persulfate $(140 \mathrm{mM})$ were prepared in water, and $\mathrm{ABTS}^{\bullet+}$ radical solution was produced by reacting 10 $\mathrm{mL}$ of the ABTS stock solution with $175 \mu \mathrm{L}$ of potassium persulfate solution. The mixture was left in the dark at room temperature for 12 to $16 \mathrm{~h}$ before use. To evaluate antioxidant capacity, the $\mathrm{ABTS}^{\bullet+}$ solution was diluted with ethanol (96\%) to obtain absorbance of $0.700 \pm 0.020$ at $734 \mathrm{~nm}$. Two milliliters of $\mathrm{ABTS}^{\bullet+}$ solution was mixed with $100 \mu \mathrm{L}$ of the WSE of samples in a cuvette, and the decrease in the absorbance was measured after $30 \mathrm{~min}$. The reagent blank was prepared by adding $100 \mu \mathrm{L}$ of ethanol instead of the sample. A calibration curve was constructed, using ascorbic acid $(2.2-0.25 \mu M)$ as standard, and the results were expressed as milligrams of ascorbic acid equivalents (AAE) per $100 \mathrm{~g}$ of cheese.

The FRAP assay was performed according to the procedure described by Benzie and Strain (1996), with some modifications. The FRAP reagent was prepared

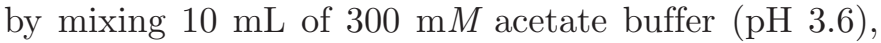
$1 \mathrm{~mL}$ of $10 \mathrm{mM}$ 2,4,6-tripyridal-s-triazine (TPTZ) in $40 \mathrm{mM} \mathrm{HCl}$, and $1 \mathrm{~mL}$ of $20 \mathrm{mM} \mathrm{FeCl}{ }_{3}$ (in the ratio 10:1:1 $\mathrm{vol} / \mathrm{vol} / \mathrm{vol}$ ). The reagent was prepared daily and warmed to $37^{\circ} \mathrm{C}$ before use. Aliquots of $100 \mu \mathrm{L}$ of WSE of samples were mixed with $2.9 \mathrm{~mL}$ of FRAP reagent and incubated at $37^{\circ} \mathrm{C}$ for $30 \mathrm{~min}$. The increase in absorbance was measured at $593 \mathrm{~nm}$ against acetate buffer ( $\mathrm{pH}$ 3.6). The blank reagent was prepared by adding distilled water instead of the sample. The calibration curve was constructed using ascorbic acid (2.2-0.25 $\mu M$ ) and the results were expressed as milligrams of AAE per $100 \mathrm{~g}$ of cheese.

The number of free thiol groups was determined according to Ellman's method 155 (Ellman, 1959), with some modifications. Two hundred fifty microliters of WSE of sample was mixed with $2.5 \mathrm{~mL}$ of $0.1 \mathrm{M}$ sodium phosphate buffer (containing $1 \mathrm{~m} M$ EDTA; pH 8.0, reaction buffer), and $50 \mu \mathrm{L}$ of DTNB [5,5'-dithiobis-(2nitrobenzoic acid)] reagent solution $(4 \mathrm{mg}$ in $1 \mathrm{~mL}$ of sodium phosphate buffer). After the solution was mixed 
Table 1. Antioxidant activity ${ }^{1}$ of Italian Brown (IB) and Italian Holstein (IH) Caciocavallo cheeses during ripening

\begin{tabular}{|c|c|c|c|c|c|c|c|c|c|c|c|c|}
\hline Ripening, d & \multicolumn{4}{|c|}{ ABTS } & \multicolumn{4}{|c|}{ FRAP } & \multicolumn{4}{|c|}{ Thiols } \\
\hline 1 & $33.55^{\mathrm{A}, \mathrm{a}}$ & 4.54 & $27.93^{\mathrm{A}, \mathrm{b}}$ & 8.58 & $2.11^{\mathrm{A}, \mathrm{a}}$ & 0.19 & $1.98^{\mathrm{A}, \mathrm{a}}$ & 0.41 & $316.72^{\mathrm{A}, \mathrm{a}}$ & 40.19 & $338.58^{\mathrm{A}, \mathrm{a}}$ & 35.06 \\
\hline 30 & $38.34^{\mathrm{B}, \mathrm{a}}$ & 5.59 & $37.18^{\mathrm{B}, \mathrm{a}}$ & 6.61 & $2.80^{\mathrm{B}, \mathrm{a}}$ & 0.48 & $2.61^{\mathrm{B}, \mathrm{a}}$ & 0.45 & $368.88^{\mathrm{B}, \mathrm{a}}$ & 33.99 & $347.57^{\mathrm{A}, \mathrm{a}}$ & 28.00 \\
\hline 60 & $40.52^{\mathrm{BC}, \mathrm{a}}$ & 6.22 & $39.83^{\mathrm{B}, \mathrm{a}}$ & 3.60 & $3.74^{\mathrm{C}, \mathrm{a}}$ & 0.70 & $3.20^{\mathrm{C}, \mathrm{b}}$ & 0.36 & $399.48^{\mathrm{C}, \mathrm{a}}$ & 41.97 & $367.62^{\mathrm{AC}, \mathrm{b}}$ & 22.97 \\
\hline
\end{tabular}

$\overline{\mathrm{A}-\mathrm{D}}$ For each parameter, different uppercase superscripts within a column indicate a statistical difference $(P<0.05)$ between means for the same genetic type at different ripening times.

${ }^{\mathrm{a}, \mathrm{b}}$ For each parameter, different lowercase superscripts within a row indicate a statistical difference $(P<0.05)$ between means for different genetic types.

${ }^{1}$ ABTS $=2,2$ '-azino-bis-3-ethylbenzothiazoline-6-sulfonic acid radical scavenging assay (values expressed as milligrams of ascorbic acid equivalents per $100 \mathrm{~g}$ ); FRAP = ferric-reducing antioxidant power assay (values expressed as milligrams of ascorbic acid equivalents per $100 \mathrm{~g}$ ); Thiols $=$ thiol assay [values expressed as $\mu M$ of thiol groups (SH)].

and allowed to stand at room temperature $\left(25^{\circ} \mathrm{C}\right)$ for 30 min, absorbance was read at $412 \mathrm{~nm}$. Reaction buffer was used instead of sample as a reagent blank. A molar extinction coefficient of $14.150 \mathrm{M}^{-1} \mathrm{~cm}^{-1}$ was used to calculate moles of thiol groups $(\mathbf{S H})$. The results were expressed as concentration $(\mu M)$ of $\mathrm{SH}$. Each determination and measurement was made in triplicate.

Statistical analysis was performed using the general linear model (GLM) procedure of SAS software (SAS Institute, 1996), using a 2-factor model without interactions:

$$
\mathrm{y}_{i j}=\mu+\alpha_{i}+\beta_{j}+\varepsilon_{i j}
$$

where $\mathrm{y}_{i j}$ is the observation; $\mu$ is the overall mean; $\alpha_{i}$ is the fixed effect of the $i$ th GT $(i=1,2) ; \beta_{j}$ is the fixed effect of the $j$ th ripening time $(j=1,2,3,4$, $5)$; and $\varepsilon_{i j}$ is the random error. Before setting the values, expressed as a percentage, they were subjected to angular transformation. Student's t-test was used for all variable comparisons. Differences between means at the $95 \%(P<0.05)$ confidence level were considered statistically significant.

The antioxidant activity of WSE of Caciocavallo cheeses was assessed by ABTS, FRAP, and thiol assays during ripening for $150 \mathrm{~d}$ (Table 1). In the last years, several methods have been developed to assess total antioxidant capacity because of the lack of standard quantification methods and the interactions among different antioxidant components (Schlesier et al., 2002). Several studies have reported that antioxidant activity depends on the system used (Janaszewska and Bartosz, 2002; Bauzaite et al., 2003) and, therefore, it recommended to base any conclusions on at least 2 different test systems (Moon and Shinamoto, 2009). The ABTS assay is a method to screen antioxidant activity that is applicable to both lipophilic and hydrophilic antioxidants (Re et al., 1999). The FRAP assay uses antioxidants as reductants in a redox-linked colorimetric method, using an easily reduced oxidant system present in stoichiometric excess. The thiol assay measures the number of thiol groups (SH), such as glutathione and protein thiol groups, which play an essential role as antioxidants. These compounds can act as free radical scavengers and chelators of metal ions.

In general, the results showed that all tested samples exhibited antioxidant activity at $1 \mathrm{~d}$ of ripening: the average ABTS value was $30.73 \mathrm{mg}$ of AAE/100 $\mathrm{g}$, the FRAP value was $2.04 \mathrm{mg}$ of AAE/100 g, and the thiol value was $327.65 \mu M \mathrm{SH}$. Antioxidant activity increased significantly during ripening $(P<0.05)$. In particular, the average values varied from $33.55(1 \mathrm{~d})$ to 44.70 $\mathrm{mg}$ of AAE/100 g $(150 \mathrm{~d})$ in the ABTS assay, from 2.11 to $4.35 \mathrm{mg}$ of AAE/100 g in the FRAP assay, and from 316.72 to $462.58 \mu M \mathrm{SH}$ in the thiol assay. This increase is strictly connected to the increasing concentration and bioavailability of antioxidant compounds with beneficial effects on the consumer's health. In this regard, Higurashi et al. (2007) suggested that cheese antioxidant peptides might have a beneficial suppressive effect on abdominal adipose accumulation and could prevent the development of metabolic syndrome. Furthermore, the increase in antioxidant activity could further prevent oxidation reactions during storage of cheese and increase its nutritional value (Gómez-Ruiz et al. 2008). Our results are in agreement with those reported by Gupta et al. (2009), who observed an increase in antioxidant activity as ripening proceeded in Cheddar cheese samples, reaching a maximum value during the fourth month. In contrast, Bottesini et al. 
(2013) reported that antioxidant activity in Parmigiano Reggiano cheese remained constant during ripening, suggesting that the peptides and proteins are not particularly affected by biochemical processes during aging. During ripening of cheese, hydrolysis of casein by coagulants, plasmin, and starter and nonstarter bacterial proteases and peptidases lead to the formation of water-soluble peptides and free amino acids (Fox et al., 1994). The presence of small peptides and free amino acids is attributed to the role played by bacterial proteinases and peptidases in the degeneration of primary proteolytic products from $\alpha_{\mathrm{S}_{1}} \mathrm{CN}$ and $\beta-\mathrm{CN}$ produced by chymosin and plasmin, respectively (Singh et al., 1997). Casein solubilization is also influenced by the technique of stretching used during Caciocavallo cheesemaking. Gagnaire et al. (2011) observed, in cheese from Ragusa, that casein degradation is greatly increased by plasmin action, in agreement with the stretching used during cheesemaking at 70 to $80^{\circ} \mathrm{C}$ and the presence of residual chymosin, which is known to be active during long periods of aging in other types of hard cheeses. The heat treatment of pasta filata cheese, in addition, exposes reactive thiol groups, which can form disulfide links with other reactive thiol groups and disulfide bridges through thiol group-exchange reactions.

Analysis of variance showed a significant effect of GT and ripening time on antioxidant activity of Caciocavallo cheeses $(P<0.001)$. In general, IB cheese had higher antioxidant activity than IH cheese $(P<0.05)$. Chiang and Chang (2005) highlighted the positive correlation between protein content and antioxidant activity. In fact, IB cheese had a higher protein content than IH cheese ( 45.37 vs. $44.77 \%$, respectively; $P<0.05$ ) as reported in our earlier study (Perna et al., 2014). When comparing Caciocavallo cheese made from IB and IH milks at $1 \mathrm{~d}$ of ripening, the differences between the average ABTS values were statistically significant $(P<$ $0.05)$, whereas no significant differences were found in FRAP and thiol values.

The ABTS values increased from $33.55 \mathrm{mg}$ of $\mathrm{AAE} / 100 \mathrm{~g}$ at $1 \mathrm{~d}$ of ripening to $44.70 \mathrm{mg}$ of $\mathrm{AAE} / 100$ $\mathrm{g}$ at $150 \mathrm{~d}$ in IB cheese, and from $27.93 \mathrm{mg}$ of AAE/100 $\mathrm{g}$ at $\mathrm{d} 1$ of ripening to $44.08 \mathrm{mg}$ of $\mathrm{AAE} / 100 \mathrm{~g}$ at 150 $\mathrm{d}$ in IH cheese. The ABTS radical scavenging activity increased by about 33 and $58 \%$ over the initial value in IB and IH cheeses, respectively. No significant differences were observed at 30 and $60 \mathrm{~d}$ of ripening $(P>$ 0.05), whereas, at the end of ripening, IB cheese had an ABTS value significantly higher than that of IH cheese $(P<0.05)$.

Antioxidant activity measured by the FRAP assay increased by more than $106 \%$ in IB cheese and by about $103 \%$ in IH cheese. Comparing Caciocavallo cheeses, the differences between the average FRAP values were statistically significant at 60 and $90 \mathrm{~d}$ of ripening $(P<$ $0.05)$.

The trend of antioxidant activity evaluated by thiol assay confirmed the results obtained by ABTS and FRAP assays: antioxidant activity of IB cheese was more than twice that of IH cheese. The differences between products were statistically significant at the end of ripening (90 and $150 \mathrm{~d} ; P<0.05$ ). Gupta et al. (2009) found that the antioxidant activity in Cheddar cheese varied depending on the rate of formation of soluble peptides (proteolysis). The same authors, in a later work (Gupta et al., 2013), showed that angiotensin-I converting enzyme (ACE) inhibitory activity increased with the increase in the protein content of the WSE of Cheddar cheeses.

Previously, we reported that the trend for proteolysis in Caciocavallo cheese was greatly influenced by GT $(P<0.05$; Perna et al., 2014). This result was linked to genetic variants of caseins, which are an important differential characteristic because they influence cheese structure and, therefore, the action of proteolytic enzymes during ripening (Mariani et al., 2002). In fact, it was found that proteolysis phenomena occurring during cheese processing are more intense in cheese made from IB milk. In the current study, the IB cheese showed a higher solubilization of casein compared with IH cheese. In particular, IB cheese showed higher proteolysis $(P<0.05)$ of $\beta$ - and para- $\kappa-\mathrm{CN}$ in each interval of ripening considered. The greater degradation of $\alpha_{S 1}-\mathrm{CN}$ in IH Caciocavallo cheese is probably due to the greater $\mathrm{pH}$ and moisture content that influence its susceptibility to hydrolysis by proteases (Creamer, 1985). Lourens-Hattingh and Viljoen (2001) suggested that antioxidant activity is closely linked to milk protein degradation. Similar results were obtained by Hajirostamloo (2010), who reported that the concentration of ACE-inhibitory peptides depends on a balance between their formation and further breakdown into inactive peptides and AA that, in turn, depends on storage time and conditions. Conversely, variation in antioxidant activity is linked to the possible aggregation of peptide processes that occur during the enzymatic hydrolysis of whey protein and $\mathrm{CN}$, with formation of macro-aggregates that reduce the antioxidant capacity (Pattorn et al., 2012).

In conclusion, cheese is a complex food matrix containing a large number of different peptides, some of which are characterized by bioactivity useful to the consumer's health. The data obtained in this study show that variability in the antioxidant power of the cheeses was a function of genetic type (breed) and ripening time. Cheese from Italian Brown milk had greater antioxidant activity, probably because of its higher protein content compared with cheese made from Italian Hol- 
stein milk. Moreover, antioxidant activity varied during ripening, depending on the rate of formation of soluble peptides. To date, few studies have evaluated the effect of genetic type on antioxidant capacity of pasta filata cheeses; thus, this study forms the basis of new knowledge that could lead to the production of a pasta filata cheese with specific nutraceutical characteristics.

\section{REFERENCES}

Addeo, F., L. Chianese, A. Salzano, R. Sacchi, U. Cappuccio, P. Ferranti, and A. Malorni. 1992. Characterization of the $12 \%$ trichloroacetic acid-insoluble oligopeptides of Parmigiano-Reggiano cheese. J. Dairy Res. 59:401-411.

Battistotti, B., and C. Corradini. 1993. Italian cheese. Pages 221-243 in Cheese: Chemistry, Physics and Microbiology. Vol. 2. P. F. Fox, ed. Chapman and Hall, London, UK.

Bauzaite, R., P. R. Venscutonis, D. Gruzdiene, D. Tirzite, and G. Tirzitis. 2003. Radical scavenging and antioxidant activity of various plants grown in Lithuania. Pages 183-193 in Food Technology and Quality Evaluation. R. Dris and A. Sharma, ed. Science Publishers, Enfield, NH.

Benzie, I. F. F., and J. J. Strain. 1996. The ferric reducing ability of plasma (FRAP) as a measure of "antioxidant power": The FRAP assay. Anal. Biochem. 239:70-76.

Bottesini, C., S. Paolella, F. Lambertini, G. Galaverna, T. Tedeschi, A. Dossena, R. Marchelli, and S. Sforza. 2013. Antioxidant capacity of water-soluble extracts from Parmigiano-Reggiano cheese. Int. J. Food Sci. Nutr. 64:953-958

Chiang, S. H., and C. Y. Chang. 2005. Antioxidant properties of caseins and whey proteins from colostrums. J. Food Drug Anal 13:57-63.

Colbert, L. B., and E. A. Decker. 1991. Antioxidant activity of an ultrafiltration permeate from acid whey. J. Food Sci. 56:1248-1250.

Creamer, L. K. 1985. Water absorption by renneted casein micelles, Milchwissenschaft 40:589-591.

De Angelis, M., and M. Gobbetti. 2011. Pasta-filata cheeses: Traditional pasta-filata cheese. Pages 745-752 in Encyclopedia of Dairy Sciences. Vol. 1. 2nd ed. J. W. Fuquay, P. F. Fox, and P. L. H. McSweeney, ed. Academic Press, San Diego, CA.

De Marchi, M., G. Bittante, R. Dal Zotto, C. Dalvit, and M. Cassandro. 2008. Effect of Holstein Friesian and Brown Swiss breeds on quality of milk and cheese. J. Dairy Sci. 91:4092-4102.

Donkor, O. N., A. Henriksson, T. K. Singh, T. Vasiljevic, and N. P. Shah. 2007. ACE-inhibitory activity of probiotic yoghurt. Int. Dairy J. 17:1321-1331.

Ellman, G. L. 1959. Tissue sulfhydryl groups. Arch. Biochem. Biophys. $82: 70-77$.

European Union. 2004. Regulation (EC) No. 853/2004 of 29 April 2004 laying down specific rules for food of animal origin. Off. J. L226:22-82.

Fox, P. F., T. K. Singh, and P. L. H. McSweeney. 1994. Proteolysis in cheese during ripening. Pages 1-31 in Biochemistry of Milk Products. A. T. Andrews and J. Varley, ed. Royal Society of Chemistry, Cambridge, UK

Fridovich, I. 1999. Fundamental aspects of reactive oxygen species, or what's the matter with oxygen? Ann. N. Y. Acad. Sci. 893:13-18.

Gagnaire, V., S. Carpino, C. Pediliggieri, J. Jardin, S. Lortal, and G. Licitra. 2011. Uncommonly thorough hydrolysis of peptides during ripening of Ragusano cheese revealed by tandem mass spectrometry. J. Agric. Food Chem. 59:12443-12452.

Gómez-Ruiz, J., I. Lopez-Exposito, A. Pihlanto, M. Ramos, and I. Recio. 2008. Antioxidant activity of ovine casein hydrolysates: Identification of active peptides by HPLC-MS/MS. Eur. Food Res. Technol. 227:1061-1067.
Gupta, A., B. Mann, R. Kumar, and R. Sangwan. 2009. Antioxidant activity of Cheddar cheeses at different stages of ripening. Int. J. Dairy Technol. 62:339-347.

Gupta, A., B. Mann, R. Kumar, and R. B. Sangwan. 2013. ACE-inhibitory activity of Cheddar cheeses made with adjunct cultures at different stages of ripening. Adv. Dairy Res. 1:102 http://dx.doi. org/10.4172/2329-888X.1000102.

Hajirostamloo, B. 2010. Bioactive component in milk and dairy product. World Acad. Sci. Eng. Technol. 72:162-166.

Hernandez-Ledesma, B., A. Davalos, B. Bartolome, and L. Amigo. 2005a. Preparation of antioxidant enzymatic hydrolysates from $\alpha$-lactoalbumin and $\beta$-lactoglobulin. Identification of active peptides by HPLC-MS/MS. J. Agric. Food Chem. 53:588-593.

Hernandez-Ledesma, B., B. Miralles, L. Amigo, M. Ramos, and I. Recio. 2005b. Identification of antioxidant and ACE-inhibitory peptides in fermented milk. J. Sci. Food Agric. 85:1041-1048.

Higurashi, S., Y. Kunieda, H. Matsuyama, and H. Kawakami. 2007 Effect of cheese consumption on the accumulation of abdominal adipose and decrease in serum adiponectin levels in rats fed a calorie dense diet. Int. Dairy J. 17:1224-1231.

Janaszewska, A., and G. Bartosz. 2002. Assay of total antioxidant capacity: Comparison of four methods as applied to human blood plasma. Scand. J. Clin. Lab. Invest. 62:231-236.

Korhonen, H., and A. Pihlanto. 2006. Bioactive peptides: Production and functionality. Int. Dairy J. 16:945-960.

Kudoh, Y., S. Matsuda, K. Igoshi, and T. Oki. 2001. Antioxidative peptide from milk fermented with Lactobacillus delbrueckii ssp. bulgaricus IFO 13953. J. Jpn. Soc. Food Sci. Technol. 48:44-50.

Lourens-Hattingh, A., and B. C. Viljoen. 2001. Yogurt as probiotic carrier food. Int. Dairy J. 11:1-17.

Mariani, P., A. Summer, P. Formaggini, and M. Malacarne. 2002. La qualita casearia 348 del latte di differenti razze bovine. La Razza Bruna Italiana 1:7-13.

Meisel, H. 1998. Overview on milk protein-derived peptides. Int. Dairy J. 8:363-373.

Moon, J.-K., and T. Shinamoto. 2009. Antioxidant assays for plant and food components. J. Agric. Food Chem. 57:1655-1666.

Pattorn, S., Y. Horimoto, P. Hongsprabhas, and R. Y. Yada. 2012. Influence of aggregation on the antioxidative capacity of milk peptides. Int. Dairy J. 25:3-9.

Perna, A., A. Simonetti, I. Intaglietta, and E. Gambacorta. 2014. Effects of genetic type, stage of lactation, and ripening time on $\mathrm{Ca}-$ ciocavallo cheese proteolysis . J. Dairy Sci. 97:1909-1917.

Re, R., N. Pellegrini, A. Proteggente, A. Pannola, M. Yang, and C. Rice-Evans. 1999. Antioxidant activity applying en improved ABTS radical cation decolorization assay. Free Radic. Biol. Med. 26:1231-1237.

Rival, S. G., C. G. Boeriu, and H. J. Wichers. 2001. Caseins and casein hydrolysates. Antioxidative properties and relevance to lipoxygenase inhibition. J. Agric. Food Chem. 49:295-302.

Saito, T., T. Nakamura, H. Kitazawa, Y. Kawai, and T. Itoh. 2000. Isolation and structural analysis of antihypertensive peptides that exist naturally in Gouda cheese. J. Dairy Sci. 83:1434-1440.

SAS Institute. 1996. SAS User's Guide: Statistics. Version 7 ed. SAS Institute Inc., Cary, NC.

Schlesier, K., M. Harwat, V. Bohm, and R. Bitsch. 2002. Assessment of antioxidant "activity by using different in vitro methods. Free Radic. Res. 36:177-187.

Singh, T. K., P. F. Fox, and A. Healy. 1997. Isolation and identification of further peptides in the diafiltration retentate of the watersoluble fraction of Cheddar cheese. J. Dairy Res. 64:433-443.

Smacchi, E., and M. Gobbetti. 1998. Peptides from several Italian cheeses inhibitory 374 to proteolytic enzymes of lactic acid bacteria Pseudomonas fluorescens ATCC 948 and to the angiotensin I converting enzyme. Enzyme Microb. Technol. 22:687-694.

Virtanen, T., A. Pihlanto, S. Akkanen, and H. Korhonen. 2007. Development of antioxidant activity in milk whey during fermentation with lactic acid bacteria. J. Appl. Microbiol. 102:106-115. 